ELORE (ISSN 1456-3010), vol. $12-2 / 2005$.

Julkaisija: Suomen Kansantietouden Tutkijain Seura ry. Taitto: Jukka Talve ja Outi Fingerroos.

[http://cc.joensuu.fi/ /oristi/2_05/hak2_05.pdf]

\title{
KIRJA-ARVIO:
}

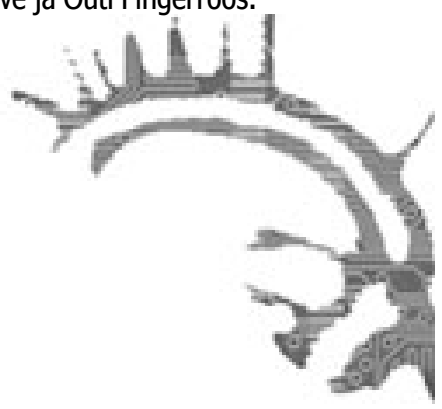

\section{UUDENLAISTA SANANLASKUTUTKIMUSTA}

Outi Laubakangas 2004: Puheesta ibminen tunnetaan. Sananlaskujen funktiot sosiaalisessa vuorovaikutuksessa. Suomalaisen Kirjallisunden Seuran Toimituksia 1001. Helsinki: Suomalaisen Kirjallisunden Seura. 318 s.

Pekka Hakamies

Outi Lauhakankaan sosiaalipsykologian oppiaineeseen laatiman väitöskirjan lähtökohtana on oletus, että sananlaskuja käytetään yleensä sosiaalisesti herkissä tilanteissa, joissa on vaikeaa sanoa toiselle oma käsitys asiasta ja arvostella toista suoraan. Teoksen nimessä esitettyä tutkimustehtävää on tekstissä kuormitettu lisää teoreettisemmilla haasteilla: miten kulttuuristen arvojen ja asenteiden välitysmekanismit saattavat toimia sananlaskuja käyttävässä puheessa. Varsinaiseksi tutkimusongelmaksi on kiteytynyt kysymys: "Voidaanko väittää, että sananlaskujen kaltaiset kielelliset välineet otetaan avuksi erityisesti emotionaalisesti jännittyneissä tilanteissa, jolloin tarvitaan tavanomaisen vuorovaikutuksen sijaan 'kolmannen tahon' puhetta?' Keskusteluun otetaan mukaan sivullinen, kollektiivisen perinteen auktoriteetti, johon puhuja voi turvautua eikä siten ole yksin vastuussa mielipiteestään ja sanomastaan.

\section{SANANLASKUT JA PSYKOLOGINEN PAREMIOLOGIA}

Lauhakankaalla on teoreettisena lähtökohtana psykologisessa paremiologisessa eli sananparsiin kohdistuvassa tutkimuksessa yleinen näkemys sananlaskuista universaalina perinnelajina, vaikka laji saakin omia piirteitään kussakin kulttuurissa. Universaaleja ominaisuuksia, joiden avulla laji voidaan tunnistaa muusta puheesta, ovat muiden muassa traditionaalisuus, kokemuksen tiivistymä ja esteettisesti kiteytynyt, useimmiten metaforinen ja yleistävä, helposti mieleen jäävä, lyhyehkö, muodoltaan suljettu, itsenäisen ajatuksen sisältämä lause. Määritelmä on saatu paremiologisesta tutkimuskirjallisuudesta, joka perustuu pääasiassa eurooppalaiseen kulttuuriin, mutta johon liittyy runsaasti ennen kaikkea Afrikan ja Lähi-idän kansojen perinteen tutkimusta. Lauhakangas on tietoinen vaarasta, että tutkija tekee yleistyksiä pelkästään oman kulttuurinsa perusteella, ja niinpä hän on pyrkinyt saamaan aineis- 


\section{Pekka Hakamies}

tonsa maantieteellisesti ja kulttuurisesti mahdollisimman laajaksi. Loppuluvussa hän vielä varta vasten pohtii sitä, kuinka yhteismitallisia ovat sananlaskuiksi luokitellut puhumisen lajit eri kulttuureissa ja miten eri kulttuureissa käytetään sananlaskuja. Lisäksi Lauhakangas kokoaa huomioita siitä, kenen ja millaisessa asemassa olevan sopii käyttää sananlaskuja.

Edempänä määritelmä täydentyy vielä toteamuksella, että sananlasku ei kirjaimellisesti ymmärrettynä sovi tilanne- ja tekstikontekstiinsa. Siten sananlasku erottuu normaalista puheen virrasta ja katkaisee sen hetkeksi. Lauhakangas käsittelee sananlaskuja ennen kaikkea emotionaalisina, kognitiivisina ja sosiaalisina strategioina, jolloin keskeistä on niiden käyttö ja kontekstuaalinen informaatio.

\section{Aineistosta TUTKIMUKSEKsi}

Lauhakankaan teos perustuu paremiologisesta kirjallisuudesta saatuihin esimerkkitapauksiin. Empiirinen aineisto on peräisin suureksi osaksi kontekstipainotteisesta tutkimuskirjallisuudesta eri puolilta maailmaa, jolloin siinä painottuu eurooppalaisen ohella orientin ja Afrikan sananparsikulttuuri. Mukana on myös aineistoa Amerikan alkuperäiskansoilta, mutta itäinen Aasiala (Kiina, Japani) on kirjoittajan mukaan niukasti edustettu, koska sieltä ei ole ollut saatavilla kuvauksia sananparsien käyttötilanteista. Lauhakangas on etsinyt lisää aineistoa myös kansanrunousarkistosta, kaunokirjallisuudesta ja muusta tutkimuskirjallisuudesta sekä kirjannut itse muistiin havaitsemiaan sananlaskujen käyttötapauksia. Varsinkin viimeksi mainittu on arvokas osa tutkimuksessa, sillä sananlaskujen "keruu" tällä tavoin kenttätyönä on hidasta ja vaivalloista. Lauhakankaan näkökulmaa voidaan pitää tavallaan esityskeskeisenä, koska kohteena on sananlaskupuhe ja esitystilanteessa syntyvät merkitykset, eivätkä pelkät sananlaskutekstit vailla esitysyhteyttään. Kirjallisuus on käyty huolellisesti läpi, ja työstä näkyy erityisesti hyvä perehtyneisyys sananlaskujen käytön tutkimusta koskevaan kirjallisuuteen.

Teoksen tutkimuksellisen rungon muodostaa empiirisen aineiston luokittelu kolmeen pääryhmään ja niiden sisällä alaryhmiin. Tekijällä on runsaasti kokemusta kansainvälisen sananlaskuaineiston luokittelusta ja myös niistä ongelmista, joita kohdataan lajiteltaessa usein semantiikaltaan väljiä ja monitulkintaisia sananlaskuja merkityksen mukaisesti ryhmiin. Outi Lauhakankaan kiinnostus ilmiöiden hahmottamiseen eri ryhmiin jakamalla näkyy siitä, että hän on luokitellut myös sosiaalisen vuorovaikutuksen eri tilanteet ja yhdistänyt niihin sananlaskuja. Hän ei katso, että sananlaskuaineistoista voitaisiin suoraan lukea, millaisia arvomaailmoja eri kansoilla tai kulttuureilla on. Sen sijaan on mahdollista tarkastella, millaista metaforista kuvastoa ja päättelymalleja sananlaskuissa käytetään ja pidetään yllä.

Lauhakangas käyttää Thomas Kuhnin paradigma-käsitettä sananlaskupuheen funktioiden jakamiseen kolmeen pääryhmään, jotka ovat perinteen voima, konfliktien ratkaisu ja ybteenkuuluvuus. Paradigma-käsitteen käyttöä pääryhmän kategoriana olisi voinut perustella enemmän. Nyt perusteet tulevat lyhyehkösti esiin edellisen pääluvun lopussa sekä loppuviitteessä. Paradigma on Lauhakankaan näkemyksen 
mukaan "tiettyjen perustavanlaatuisten taustaoletusten mukainen ajattelutapa" (s. 275). Kuhunkin paradigmaan kuuluu muutama kategoriaryhmä, yhteensä kymmenkunta kategoriaa sen mukaan, millainen tehtävä sananlaskuilla on sosiaalisessa kanssakäymisessä. Kriittinen lukija voi toisinaan epäillä, kuinka selkeästi ja yksiselitteisesti aineisto luokittuu vaikkapa "perustelijan puheeksi", "itsensä vakuuttajan puheeksi" tai "puolustelijan ja selittelijän puheeksi", mutta useimmiten jaottelu on aivan perusteltu. Lauhakangas myöntää työssään havainneensa luokittamisen vaikeudet, eikä hän halua esittää kategoriajärjestelmäänsä kaiken kattavana ja ainoana oikeana vaan pikemmin havainnollistamisen välineenä.

Sosiaalipsykologian antia työssä on ennen kaikkea "sosiaalipsykologisoinnin" kuvaaminen - kuinka erilaisille asioille esitetään yksinkertaistavia psykologisoivia selityksiä, jollainen voi olla myös "kansanluonne" sananlaskujen todistamana. Lauhakangas osoittaa, että sosiaalispsykologian käsitteillä on vastaavuutta sananlaskujen tematiikan kanssa. Arkipäättely ja persoonallinen rationaalisuus ovat keskeisesti huomion kohteena. Lauhakankaan kiinnostus kytkeytyy arkiajattelun tutkimisen traditioon, joka eri auktoriteettien mukaan eroaa narratiivisuudessaan paradigmaattisesta argumentointitavasta. Sananlasku on ennen kaikkea retorinen tehokeino, jolla puhuja voi lisätä luottamusta jo valitsemaansa näkökantaan. Sananlaskut eivät määrittele tilannetta, vaan tilannearvion, puhujan tulkinnan tilanteesta.

\section{URAAUURTAVA TUTKIMUS}

Lauhakankaan tavassa eritellä sananlaskujen funktioita oppositioparien kautta voi oppihistorioitsija nähdä selkeän linjan aikaisempaan suomalaiseen paremiologiaan. Lauhakangas tuo oman tutkija- ja kirjoittajapersoonansa työssä esiin kirjoittamalla varsin paljon yksikön 1. persoonassa vailla "tieteellisen passiivin" retorista verhoa, mikä on hyvä ja luonteva tapa, koska valinnat ja ratkaisut ovat kuitenkin hänen tekemiään. Työnsä tulokset Lauhakangas on kiteyttänyt kertauksenomaisesti kahdeksaksi selkeäksi väitteeksi, joissa tulevat esiin sananlaskujen ominaislaatu epäsuorana, kolmannen tahon puheena ja kolme paradigmaa.

Outi Lauhakankaan väitöskirja on valmistunut sosiaalipsykologian oppiaineeseen, mutta siinä on runsaasti luettavaa myös sananlaskuista kiinnostuneelle folkloristille. Itse asiassa työ näyttää ainakin minun silmissäni enemmän folkoristisparemiologiselta kuin sosiaalipsykologiselta. Omassa lajissaan työ on uraauurtava. Suomalaisesta paremiologiasta on puuttunut kontekstuaalinen, sosiaalitieteellisesti orientoitunut tutkimussuunta, ja eurooppalaisessakin tutkimuksessa se on ollut harvinainen. Nyt tähän suuntaan on otettu merkittävä askel, ja samalla on esitetty vastaus teoreettisesti tärkeään kysymykseen: "Mitä varten sananlaskuja käytetään?" Käsityksemme sananlaskujen ja yleisemminkin metaforisen puheen käytöstä osana sosiaalista interaktiota on oleellisesti syventynyt Lauhakankaan tutkimuksen myötä. 


\section{PekKa Hakamies}

Dosentti Pekka Hakamies työskentelee erikoistutkijana Karjalan tutkimuslaitoksessa Joensuun yliopistossa. 